\title{
THE INFLUENCE OF PPM UPON THE STERILITY OF THE IN VITRO CULTURES IN EUROPEAN BEECH (FAGUS SYLVATICA L.)
}

\author{
WOJCIECH KRAJ, ADAM DOLNICKI \\ Department of Forest Tree Physiology, Agricultural University \\ Al. 29 Listopada 46, 31-425 Cracow, Poland \\ e-mail: rldolnic@cyf-kr.edu.pl \\ (Received: February 12, 2003. Accepted: July 15, 2003)
}

\begin{abstract}
Investigations were conducted on the strongly infested by microbes embryos isolated from seed stratified in non-sterile conditions or from tree buds. The results showed, that PPM (Plant Preservative Mixture, produced by Plant Cell Technology, Inc.) was very useful for increasing the percentage of sterile cultures disinfected in a 5\% solution of $\mathrm{NaOCl}$. The best way of applying PPM turned out to be adding the substance directly to the growing medium. At the concentration of 2 or $4 \mathrm{~cm}^{3} \times \mathrm{dm}^{-3}$ of PPM there was an $30 \%$ increase in percentage of sterile of in vitro cultures developed from embryos and $70-80 \%$ of cultures developed from buds, as compared with the control without PPM. At the range of concentrations employed in this study, no negative effects of PPM upon the development and growth of callus were observed.
\end{abstract}

KEY WORDS: Fagus sylvatica L., PPM, embryos, buds, sterilization, tissue cultures.

\section{INTRODUCTION}

Obtaining sterile cultures is a prerequisite for in vitro plant culturing. There are relatively few methodical papers dealing with sterilization of plant material. In papers concerning micropropagation of trees very few - if any - details are given in respect to the sterilization techniques employed, usually with no information about how big percentage of sterile cultures was obtained.

Seeds and buds of European beech are difficult to sterilize, because they are usually strongly infested by microbes, and because infiltration ability of the sterilizing agent into folded cotyledons in embryos and folded leaves in buds is limited (Kraj and Dolnicki 1998; Nadel et al. 1991). Sterile cultures are usually obtained by applying $\mathrm{HgCl}_{2}$ (Ahuja 1984; Chalupa 1985, 1987, 1990; Kraj and Dolnicki 1998; Nadel et al. 1991), which is strongly toxic for humans and believed to be a mutagenic factor.

To reduce the infestation of in vitro cultures the antibiotics and fungicides were also applied; however, these substances are specific towards certain species of microbes, can be easily decomposed in an autoclave, they can be toxic or detrimental in other way for the cultures of vascular plants (Guri and Kishor 1998).

The firm Plant Cell Technology patented in 1998 in the USA the PPM (Plant Preserve Mixture), which is a substance affecting a very broad spectrum of microbes, including bacteria, fungi and algae (Guri and Kishor 1998).
PPM is a mixture of two isotiazolinones (methylchloroisothiazolinone and methylisothiazolinone) with salts of magnesium (magnesium chloride, magnesium nitrate). The active compounds of PPM penetrate into the microbial cells inhibiting the citric acid cycle, the oxidative electrontransport chain and absorption of monosaccharides and amino acids (Guri and Kishor 1998). Under the influence of PPM the microbes die back; however, at the appropriate range of concentrations, PPM does not affect the vitality of explants of vascular plants and does not inhibit their development (Niedz 1998).

The aim of these investigations was evaluation of the influence of various ways application and various concentrations of PPM upon the sterility of in vitro cultures taken from embryos and buds of European beech (Fagus sylvatica L.).

\section{MATERIAL AND METHODS}

The investigations on the influence of PPM on the sterility of in vitro cultures were conducted:

a) on entire embryos (Experiment 1) or on their fragments (Experiments II-IV) isolated from seeds collected on autumn 2000 from about 90-year old tree stands in the $\mathrm{Bu}$ kowiec forest range, Baligród Forest district in the Bieszczady mountains (Eastern Carpathians); the seeds were stratified for 3 months in moist sand, in a fridge at the temperature $3^{\circ} \mathrm{C}$; 
b) on buds (Experiments V-VII) taken in March 2001 from lateral shoots of 10-15 year old beeches growing in the Tenczynek forest range, Krzeszowice Forest District, near Kraków.

The seeds and buds were washed under the tap water for 30 minutes, then put into a $96 \%$ ethanol, fired and washed in pure, sterile water. The isolated embryos (Exp. I) or their parts (Exp. II-IV) were disinfected for 20 minutes in a $5 \%$ solution of $\mathrm{NaOCl}$ with a few droplets of Tween 80 , and then washed three times in a sterile water. The scales from buds were removed, the leaf primordia (apart from the two terminal ones) were cut and disinfected for $10 \mathrm{mi}$ nutes in a $5 \% \mathrm{NaOCl}$ (Experiments V-VII).

Explants were put separately into test-tubes with $10 \mathrm{ml}$ of WPM culture medium autoclaved for 20 minutes at the temperature of $121^{\circ} \mathrm{C}$ and solidified with agar $\left(6 \mathrm{~g}^{\circ} \mathrm{dm}^{-3}\right)$ (Loyd, McCown 1980) with addition of $30 \mathrm{~g} \times \mathrm{dm}^{-3}$ of sucrose, $200 \mathrm{mg} \times \mathrm{dm}^{-3}$ of glutamine, $200 \mathrm{mg} \times \mathrm{dm}^{-3}$ of casein hydrolysate, $0.63 \mathrm{mg} \times \mathrm{dm}^{-3}$ of BAP and $11.1 \mathrm{mg}^{2} \times \mathrm{dm}^{-3}$ of 2.4-D (all compounds produced by the SIGMA). The cultures were conducted for 30 days in a dark chamber at the temperature of $23^{\circ} \mathrm{C}$.

In the investigation the PPM produced by the Plant Cell Technology, Inc., was applied.

PPM was used by adding it before autoclaving to:

a) liquid, not solidified with agar culture medium WPM, in which the explants had been soaked for 24 or 48 hours with constant mixing on the shaker before putting them into the culture medium (Experiments I-II and V-VI);

b) semi-liquid (with $3 \mathrm{~g} \times \mathrm{dm}^{-3}$ of agar) WPM culture medium, in which the explants had been encapsulated (Exp. III, IV, VI, VII);

c) the WPM culture medium solidified with agar, in which the in vitro culture had been conducted for 30 days (all experiments) (Tables 1 and 2).

As a control the explants not soaked and soaked in a culture medium without PPM were used. They were either en- capsulated or they grew on a culture medium without PPM. In each combination there were 40 explants.

The influence of PPM upon the sterility of cultures was evaluated on the basis of percentage of explants without any signs of development of microbes after 30 days of growing. Apart from that, the effect of PPM upon the vitality of cultures was estimated on the basis of the presence and appearance of callus on explants. Observations were repeated every 2-3 days, which allowed for determination of the dynamics of the appearance of microbial infestations.

\section{RESULTS}

\section{Embryos}

In the experiment no I, in which the entire embryos were sterilized, the PPM added to the growing medium in the amount of $2 \mathrm{~cm}^{3} \times \mathrm{dm}^{-3}$ or $4 \mathrm{~cm}^{3} \times \mathrm{dm}^{-3}$ only delayed the development of microbes; after 30 days of growing, none of these cultures were free of microbes. Therefore in further investigations (exp. II-IV) only fragments of embryos were employed.

Experiment no II showed a negative influence of soaking embryos for 24 or 48 hours in a fluid WPM culture medium upon the culture sterility; that referred both to culture media with and without PPM (combinations 4-12). This treatment cancelled even very light influences of PPM in the growing medium (combinations 8 and 10 compared with combination 2) (Table 1).

Similar results were obtained in the experiment no III, where apart from other treatments the fragments of embryos soaked in a culture medium containing $10 \mathrm{~cm}^{3} \times \mathrm{dm}^{-3}$ of PPM were also encapsulated. The percentage of sterile cultures grown in a culture medium containing $2 \mathrm{~cm}^{3} \times \mathrm{dm}^{-3}$ and $4 \mathrm{~cm}^{3} \times \mathrm{dm}^{-3}$ of PPM was low (15-22\%), while incase when prior to encapsulating fragments of embryos were soaked in fluid medium - either containing 5 or $10 \mathrm{~cm}^{3} \times \mathrm{dm}^{-3}$

TABLE 1. The Influence of various methods of application and various concentrations of PPM upon the sterility of in vitro cultures obtained from embryos of European beech decontaminated in $5 \% \mathrm{NaOCl}$ for 10 minutes.

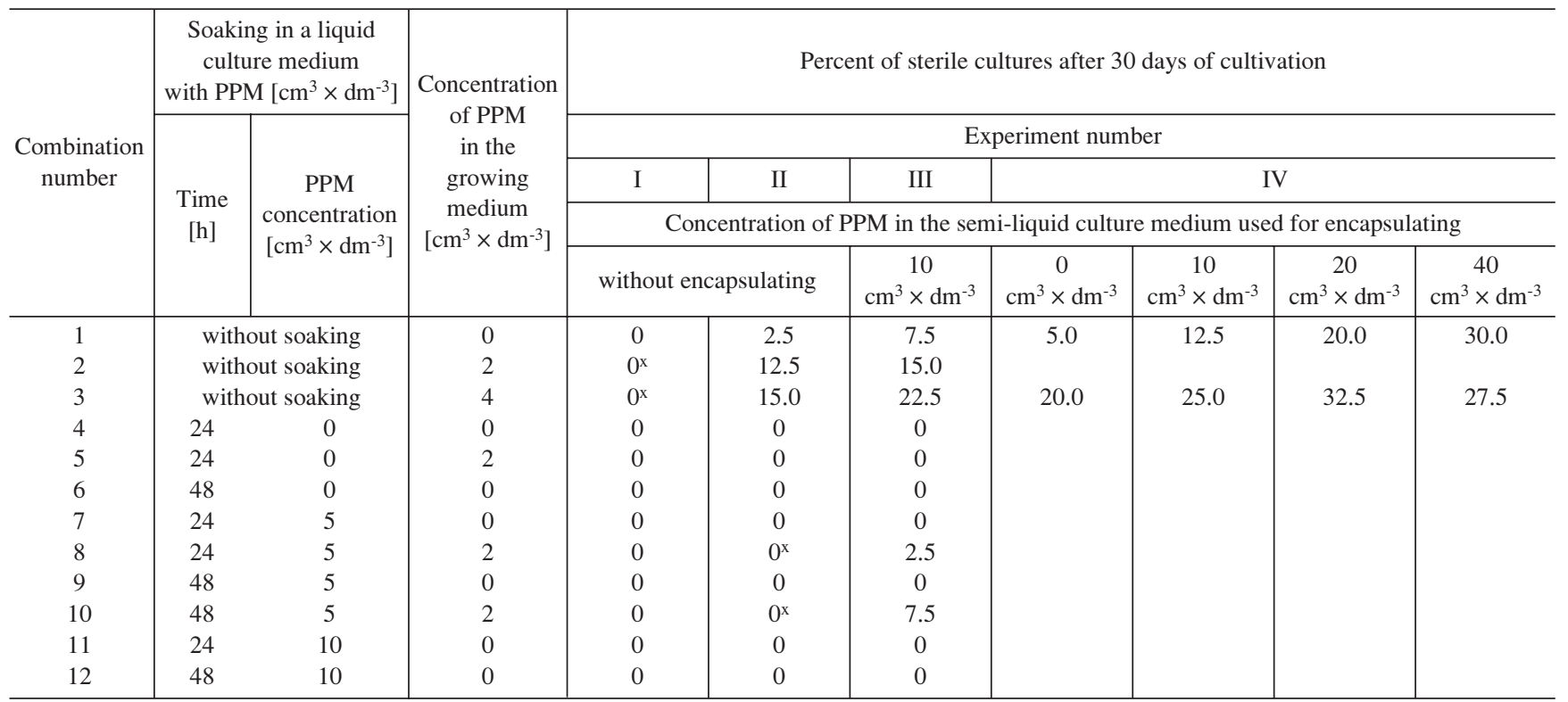

Experiment I - on the entire embryos

Experiment II-IV - on the parts of embryos

* - a few-days delay in the appearance of symptoms of the development of microbes on explants 
TABELA 2. The Influence of various methods of application and various concentrations of PPM upon the sterility of in vitro cultures obtained from buds of European beech decontaminated in $5 \% \mathrm{NaOCl}$ for 10 minutes.

\begin{tabular}{|c|c|c|c|c|c|c|c|c|c|}
\hline \multirow{5}{*}{$\begin{array}{c}\text { Combination } \\
\text { number }\end{array}$} & \multicolumn{2}{|c|}{$\begin{array}{c}\text { Soaking in a liquid } \\
\text { culture medium } \\
\text { with PPM }\left[\mathrm{cm}^{3} \times \mathrm{dm}^{-3}\right]\end{array}$} & \multirow{5}{*}{$\begin{array}{l}\text { Concentration } \\
\text { of PPM } \\
\text { in the } \\
\text { growing } \\
\text { medium } \\
{\left[\mathrm{cm}^{3} \times \mathrm{dm}^{-3}\right]}\end{array}$} & \multicolumn{6}{|c|}{ Percent of sterile cultures after 30 days of cultivation } \\
\hline & \multirow{4}{*}{$\begin{array}{c}\text { Time } \\
{[\mathrm{h}]}\end{array}$} & \multirow{4}{*}{$\begin{array}{c}\text { PPM } \\
\text { concentration } \\
{\left[\mathrm{cm}^{3} \times \mathrm{dm}^{-3}\right]}\end{array}$} & & \multicolumn{6}{|c|}{ Experiment number } \\
\hline & & & & V & VI & \multicolumn{4}{|c|}{ VII } \\
\hline & & & & \multicolumn{6}{|c|}{ Concentration of PPM in the semi-liquid culture medium used for encapsulating } \\
\hline & & & & without encapsulating & $\begin{array}{c}10 \\
\mathrm{~cm}^{3} \times \mathrm{dm}^{-3}\end{array}$ & $\begin{array}{c}0 \\
\mathrm{~cm}^{3} \times \mathrm{dm}^{-3}\end{array}$ & $\begin{array}{c}10 \\
\mathrm{~cm}^{3} \times \mathrm{dm}^{-3}\end{array}$ & $\begin{array}{c}20 \\
\mathrm{~cm}^{3} \times \mathrm{dm}^{-3}\end{array}$ & $\begin{array}{c}40 \\
\mathrm{~cm}^{3} \times \mathrm{dm}^{-3}\end{array}$ \\
\hline 1 & \multirow{3}{*}{\multicolumn{2}{|c|}{$\begin{array}{l}\text { without soaking } \\
\text { without soaking } \\
\text { without soaking }\end{array}$}} & 0 & 2.5 & 12.5 & 15.0 & 15.0 & 25.0 & 32.5 \\
\hline 2 & & & 2 & 75.0 & 70.0 & & & & \\
\hline 3 & & & 4 & 77.5 & 77.5 & 80.0 & 77.5 & 70.0 & 72.5 \\
\hline 4 & 24 & 0 & 0 & 0 & 2.0 & & & & \\
\hline 5 & 24 & 0 & 2 & 27.5 & 20.0 & & & & \\
\hline 6 & 48 & 0 & 0 & 2.5 & 0 & & & & \\
\hline 7 & 24 & 5 & 0 & 2.5 & 0 & & & & \\
\hline 8 & 24 & 5 & 2 & $32.5(20)^{\mathrm{a}}$ & $15.0(5)^{\mathrm{a}}$ & & & & \\
\hline 9 & 48 & 5 & 0 & 7.5 & 0 & & & & \\
\hline 10 & 48 & 5 & 2 & $37.5(35)^{\mathrm{a}}$ & $40.0(18)^{\mathrm{a}}$ & & & & \\
\hline 11 & 24 & 10 & 0 & 2.5 & 5.0 & & & & \\
\hline 12 & 48 & 10 & 0 & 7.5 & 2.5 & & & & \\
\hline
\end{tabular}

a - including sterile, but dead

of PPM, or without PPM - almost in all combinations the microbes developed, and the effect of PPM in the growing medium was practically cancelled.

In the experiment no IV no soaking of cotyledons in a fluid culture medium was applied. The aim of study in that experiment was the effect of the presence of various concentrations of PPM in encapsules or in culture media upon the culture sterility. It was found, that in case of lack of PPM in the growing medium, with the increasing concentration of PPM (from 10 to $40 \mathrm{~cm}^{3} \times \mathrm{dm}^{-3}$ ) in culture medium used for encapsulating, the percentage of sterile cultures increased from 12.5 to $30 \%$ (compared with $5 \%$ in the control). Growing of encapsulated embryos in a culture medium containing $4 \mathrm{~cm}^{3} \times \mathrm{dm}^{-3}$ of PPM gave more pronounced results in cases, when the concentration of PPM in the encapsule was lower. When there was no PPM in encapsule, then the percentage of sterile cultures after adding of $4 \mathrm{~cm}^{3} \times \mathrm{dm}^{-3}$ of PPM to the growing medium increased fourfold (from 5 to $20 \%$ ), after adding $10 \mathrm{~cm}^{3} \times \mathrm{dm}^{-3}$ of PPM it increased twofold (from 12.5 to $25 \%$ ), after adding 20 $\mathrm{cm}^{3} \times \mathrm{dm}^{-3}$ increased 1.6 times (from 20 to $32.5 \%$ ), while after adding $40 \mathrm{~cm}^{3} \times \mathrm{dm}^{-3}$ remained constant (in both cases about $30 \%$ of cultures turned out to be sterile) (Table 1).

In all experiments sterile cultures of embryos produced callus, so that no negative influence of PPM upon the vitality of explants and callus production was observed.

\section{Buds}

The effects of applying PPM upon the buds of European beech sterilized with $5 \% \mathrm{NaOCl}$ were much stronger than in case of embryos. Adding PPM in the amount of $2 \mathrm{~cm}^{3} \times \mathrm{dm}^{-3}$ to the growing medium in experiment no $\mathrm{V}$ increased the percentage of sterile cultures to $75 \%$ (compared with $2.5 \%$ in the control) (Table 2). Doubling the amount of PPM to $4 \mathrm{~cm}^{3} \times \mathrm{dm}^{-3}$ did not increase the effect in a convincing way $(77.5 \%$ of cultures were sterile).

Like in the case of embryos, soaking explants from buds in a fluid culture medium turned out to be disadvantageous for the in vitro culture sterility. Applying 5 and $10 \mathrm{~cm}^{3} \times \mathrm{dm}^{-3}$ of PPM for soaking buds did not increase the sterility of cultures in comparison with the non-soaked control. It also strongly limited the positive effect of PPM applied in amount of $2 \mathrm{~cm}^{3} \times \mathrm{dm}^{-3}$ to the growing medium (decrease of culture sterility from $75 \%$ to $27-37 \%$ ), and it contributed to the massive mortality of explants (Exp. V, combinations 8 and 10) (Table 2). The above presented results were supported by the results of the Experiment no VI, in which PPM was applied additionally by encapsulating the buds in a semi-liquid culture medium containing PPM in the concentration of $10 \mathrm{~cm}^{3} \times \mathrm{dm}^{-3}$. The encapsulating of buds at that level of PPM concentration did not increase the effect of this substance applied in the growing medium, while soaking in liquid culture medium with PPM or without it diminished the effects of PPM contained in the medium (Table 2).

In the experiment no VII it was ascertained, that encapsulating of European beech buds increased the percentage of cultures without any signs of development of microbes only if the concentration of PPM used for encapsulating was $20 \mathrm{~cm}^{3} \times \mathrm{dm}^{-3}$; the results were clearer at $40 \mathrm{~cm}^{3} \times \mathrm{dm}^{-3}$, but the effect was weaker (25-32\%) than with applying PPM at the concentration of $4 \mathrm{~cm}^{3} \times \mathrm{dm}^{-3}$ directly to the growing medium. It turned out also, that applying PPM to encapsulating of explants from buds in case when PPM had been added to the medium, was useless.

The highest percentage $(70-80 \%)$ of sterile, producing callus buds of European beech was obtained by applying PPM to the substrate, without any additional treatments, like soaking in a fluid culture medium with PPM or encapsulating.

\section{DISCUSSION}

Embryos isolated from beech seeds from Bieszczady mountains, stratified in non-sterile conditions indicated 
strong infestation by microbes, probably resistant to the effects of $\mathrm{NaOCl}$. It was indicated by complete (Exp. I) or almost complete (Exp. II and IV) lack of sterile cultures in case of 20 minute sterilization with a $5 \%$ solution of $\mathrm{Na}-$ $\mathrm{OCl}$ (Table 1).

Ascertained in experiment no I lack of positive influence of PPM added to the growing medium upon the sterility of cultures of entire embryos seems to be caused by the problems with penetration of the substance among the folded cotyledons. Such possibility was suggested by Bonga and Aderkas (1992), who studied the effectiveness of sterilization as related to the kind of surface and morphology of explants. It is also supported by the fact, that in other experiments (II-V) splitting the embryos into parts increased the effect of adding PPM to the growing medium.

Suggested by the producer (instruction prepared by Guri and Kalin 2000) way of applying PPM by soaking the explants previously sterilized using $5 \%$ solution of $\mathrm{NaOCl}$ for 12-96 hours in a fluid culture medium containing 5-20 $\mathrm{cm}^{3} \times \mathrm{dm}^{-3}$ of PPM was efficient for obtaining sterile cultures, among the others, of trifoliate orange Poncirus trifoliata L. (Raf.) and rough lemon Citrus janbihri Lush. (Niedz 1998). It was also efficient for obtaining sterile cultures from embryos and buds of Norway spruce Picea abies L. (Karst) (Kraj and Guri 1998).

In this study, the treatment of soaking isolated embryos (Experiments I, II and III), as well as isolated buds of European beech (Experiments V, VI) for 24 or 48 hours in a liquid culture medium WPM, containing $5 \mathrm{~cm}^{3} \times \mathrm{dm}^{-3}$ of PPM, $10 \mathrm{~cm}^{3} \times \mathrm{dm}^{-3}$ of PPM or completely without PPM affected the sterility of cultures in a negative way, or even cancelled the positive effects of adding PPM to the growing medium. This fact can be likely explained by the dispersal of microbial spores from infested explants to the surrounding explants during soaking. It is essential to note, that the concentration of PPM in the liquid culture medium was probably to low compared with the number of pathogens. According to Niedz (1998), the effective fighting of microbes needs a concentration of PPM which is proportional to the number of pathogens. What is more, soaking buds of European beech in liquid culture medium with PPM (experiments V, VI) caused browning of a part of explants during their growing.

The other way of applying PPM, recommended by Guri and Kalin (2000) is encapsulating of explants by submerging them in a semi-liquid culture medium with PPM; this method yielded in our study comparatively high percentage (about $30 \%$ ) of sterile cultures isolated from embryos (experiment no IV) and from buds (experiment no VII). The prerequisite for such high percentage of sterile cultures was a high concentration of PPM in the encapsule $\left(40 \mathrm{~cm}^{3}\right.$ $\left.\times \mathrm{dm}^{-3}\right)$.

The simplest, and at the same time the most effective method of producing sterile cultures from embryos and buds turned out to be the third method recommended by Guri and Kalin (2000), namely adding PPM directly to the growing medium. Even when applying only $2 \mathrm{~cm}^{3}$ PPM per $1 \mathrm{dm}^{3}$ of the substrate the percentage of sterile cultures from buds amounted to 70-75\% (experiments V-VII), and the additional encapsulating of explants in the semi-liquid culture medium with PPM turned out to be futile. The effects in experiments employing cultures isolated from embryos was less pronounced (15-20\% of sterile cultures); in that case, a synergistic effect of PPM applied in culture medium and in encapsule was observed.

The presence of PPM in encapsule, and especially in the growing medium, allowed, as it seems, for a constant penetration of the substance into microbes.

The WPM culture medium used in this study - enriched with $30 \mathrm{~g} \times \mathrm{dm}^{-3}$ of sucrose, $200 \mathrm{mg} \times \mathrm{dm}^{-3}$ of glutamine, and casein hydrolysate, $0.63 \mathrm{mg} \times \mathrm{dm}^{-3}$ of BAP and 1.11 $\mathrm{mg} \times \mathrm{dm}^{-3}$ of 2.4-D turned out to be very useful for callus production from explants taken either from embryos or buds of European beech. This agrees with the findings of Chalupa (1998) and Meyer and Reuther (1994). No negative influence of PPM upon the vitality of explants was found; that refers to the concentrations used in encapsulating or in the culture medium in this study. In all cases a round callus, growing at the rates comparable with callus in the control, was observed.

\section{LITERATURE CITED}

AHUJA M. 1984. In vitro introduction of organogenesis in juvenile and mature beach. Silv. Genet. 33, 6: 241-242.

BONGA J., ADERKAS P. 1992. In vitro culture in trees. Kluwer Academic Publ., Dordrecht-Boston-London. pp. 207.

CHALUPA V. 1985. In vitro propagation of Larix, Picea, Pinus, Quercus, Fagus and other species using adenine-type cytokinins and thidiazuron. Commun. Inst. For. Čechosl. 14: 65-90.

CHALUPA V. 1987. Vegetativni rozmnožovani listnatych drevin rizky a metodou in vitro. Lesnictvi 33, 6: 501-510.

CHALUPA V. 1990. Vegetativni rozmnožovani dubu (Quercus robur L.), buku (Fagus sylvatica L.) a lipy (Tilia cordata Mill.) rizky a explantatovymi kulturami. Lesnictvi 36, 7: 589-598.

CHALUPA V. 1998. In vitro propagation of european beech ( $F a$ gus sylvatica L.). Lesnictvi 44, 12: 529-534.

GURI A., KALIN M. 2000. Instructions. http://www.ppm4planttc.com/instructions.htm

GURI A., KISHOR N. 1998. Compositions and methods to prevent microbial contamination of plant tissue culture media. United States Patent 5.750.302.

KRAJ W., DOLNICKI A, 1998. Odkażanie eksplantatów buka (Fagus sylvatica L.) do kultur tkankowych. Acta Agraria et Silvestria, Ser. Silv. 36: 49-62.

KRAJ W., GURI 1998. Decontamination in immature zygotic embryos and aplical buds of different conifer species. (In): Guri 1998. Advances in controlling plant tissue culture contamination using the new biocide PPM. XXXVII Congresso Viterbo, Societa Italiana di Fisiologia Vegetale.

LOYD G., McCOWN B. 1980. Commercially feasible micropropagation of mountain laureal (Kalmia latifolia) by use of shoot-tip culture. Proc. Intl. Plant Prop. Soc. 30: 421-427.

MEIER K., REUTHER G. 1994. Factors controlling micropropagation of mature Fagus sylvatica. Plant Cell Tissue and Organ Culture 39: 231-238.

NADEL B., ALTMAN A., PLEBAN S., HÜTTERMANN A. 1991. In vitro development of mature Fagus sylvatica L. buds. J. Plant Physiol. 138, 5: 596-601.

NIEDZ R. 1998. Using isothiazolone biocides to control microbial and fungial contaminants in plant tissue cultures. Hort Technol. 8, 4: 598-601. 


\section{WPŁYW PPM NA STERYLNOŚĆ KULTUR TKANKOWYCH BUKA POSPOLITEGO (FAGUS SYLVATICA L.)}

\section{STRESZCZENIE}

Badania przeprowadzone na silnie porażonych przez drobnoustroje zarodkach izolowanych $\mathrm{z}$ nasion stratyfikowanych w nie sterylnych warunkach oraz na pąkach drzew buka wykazały przydatność PPM (Plant Preservative Mixture) (patent firmy Plant Cell Technology, Inc, Washington, DC) do zwiększania procentu sterylnych kultur eksplantatów wstępnie dezynfekowanych 5\% NaOCl. Najlepsze efekty dało wprowadzenie PPM (w stężeniu 2 i $4 \mathrm{~cm}^{3} \times \mathrm{dm}^{-3}$ ) do podłoża hodowlanego. Nie obserwowano przy tym ujemnego wpływu na proces tworzenia i wzrostu kalusa.

SŁOWA KLUCZOWE: Fagus sylvatica L., PPM, zarodki, pąki, sterylizacja, kultury tkankowe. 